\title{
TREATMENT OF LEPROSY WITH P54 (MORINAGA)
}

\author{
Dr. HIROSHI HAYATA (M. D.)
}

Leprosium Minobu Jinkyoen

In $1950, \mathrm{P}_{54}$ was for the first time administered orally to 9 cases of lepra tuberosa and as the result of which an obvious degeneration of the lepra bacilli of the modules was observed. However, in approximately 4 months some started complaining of anorexia with occasional hearttap and the treatment was discontinued. In an effort to remedy these by-effects, $30 \mathrm{mg}$ of $\mathrm{P}_{54}$ was suspended in $1 \mathrm{cc}$ refined Chaulmoogra Oil, and $1 \mathrm{cc}$ of this was injected to 4 rabbits, each weighing approximately $3,000 \mathrm{~g}$, six times weekly for 4 weeks consecutively with the intention of observing changes in their weight, appetite and induration of the injected parts. The following was observed: appetite unchanged; one rabbit showed a weight decrease; no case of incuration indicating that absorption was good. Therefore, in April 1951 it was decided to adopt this injection for the treatment of lepra patients.

The formula of $\mathrm{P}_{54}$ is as follows:

$\mathrm{C}_{2} \mathrm{H}_{5} \mathrm{SO}_{2}$<smiles>NC(N=[N+]=Cc1ccccc1)C1CCCC1</smiles>

It is in the form of brilliant white crystal with melting point at $132^{\circ} \mathrm{C}$. It does not melt easily in water, however, it is soluble in aceton, propylglycocol. chloroform, ether and alcohol. $\mathrm{P}_{54} \mathrm{~L}$ is liquidized at $25^{\circ} \mathrm{C}$ and when injected intramuscularly, it is painless and does not form induration even when administered eonsecutevelý.

Dosage is: start with 0.5 cc 3 timcs weekly, increasing gradually up to $3 \mathrm{cc}$. Simultaneous administration of $2.5 \mathrm{cc}-5 \mathrm{cc}$ of Promin by intravenous injection every other day will be excellent, and the usual by-effect of Promin, i. e. anaemia and general weekness, do not occur.

Starting in April 1951, 59 patients (4 cases of lepra maculosa, 15 lepra nervosa and 40 lepra tuberosa) were treated with $\mathrm{P}_{54} \mathrm{~L}$ alone or together with Promin for 2 to 34 months. As for the lepra maculosa cases, generally speaking, in about one year resorption of macula was observed and in 2 years sense of the affected area was restored and an investigation of the histopathological tissues of skin proved it cured. However, the thickening of ulnar nerve was not completely resorbed.

In the cases of lepra nervosa, no remarkable results were obtained, except for the restoration of sense, increase of perspiration area, cure of malum perforans pedis, and restoration of motorial paralysis where hyarulonidase was given simultaneously.

In the cases of lepra tuberosa, in appsoximately six months, absorption of nodule became obvious, together with degeneration of leprosy bacteria and in about 2 years leprosy bacteria were negative. The Mitsuda-Skin-Test turns positive approximately 6 months before leprosy bacteria prove negative. Hair and eye-brows start growing; no infiltration in the histopathological tissues of skin is observed; vegetation of connective tissue was noticed and in some cases lepro bacteria were completely negative. In such cases no erythema nodosum leprosa was observed. Cure of ulcer was also seen and there were hardly any violent complaints of leprous ueuralgia. It results in considerably less erythema nodosum leprosa than where other antileprotics are used. It is believed that simultaneous administration of Metionin will prevent such growth to a considerable extent. As a toxic manifestation, 2 cases developed jaundice but whether or not such was caused by $\mathrm{P}_{54} \mathrm{~L}$ is not known. However, there was no case of albuminuria, anaemia or leucopenia. 
Bacteriostatic action upon tubercle bacilli (Typus humanus H37RV) of $\mathrm{P}_{54} \mathrm{~L}$ is 30 times as strong as that of $\mathrm{P}_{54}$ alone. Blood concentration is highest on the 2 nd day and it is proved that it remains in a human body for 5 days, and consequently it can be said that even a small dose is effective.

$\mathrm{P}_{54} \mathrm{~L}$ is one of the drugs to be used for the treatment of leprosy.

\section{$\mathrm{P}_{54} \mathrm{~L}$ によろ治癩効 果}

身延深敬園 医学博士 早田哠

（昭和29年 4 月 15 日受稿特掲）

\section{緒言}

1954年 Faget による瀨のプロミン療法発表以来，種々 の化合物が合成され治療成績は劃期的の進歩を来し，19 53 年 2 月第 5 回国際癩学会に於て Leper の用語を癈止 して Leprosy patient の術語を使用する様に決議され， 宿命的の瀨者の語は辞書から影を消すとととなつた。瀨 も他の疾病と同様に全治の可能性のまるととを無言の裡 に認められたるのであり御同慶にたえない。

最初抗結核䑤として登場したプロミンは種々の副作用 のため其の目的を達せず，其後に表れたストマイ，パス の出現はプロミン系の薬凨の追求の必要がない、迄化好影 響を与えたが，一方逆儿瀨に対してはストマイ，パスは 余り著効を示さず, 同じ抗酸性菌でも, 癭と結核とは其 の影響する薬鼡にはつきり一線を劃して居るととを示し て居る。

1946年以来 Domagk により提唱された一連のチオセ ミカルバゾーンのアロマチックアルデヒド化合物は抗結 核郕として新らしく登場し，其内特にパラアセチールア ミノバンゾアルデヒドチオセミカルバン゙ーン (Tibion) とベラエチールスルフォニールベンッアルデヒドチオセ ミカルバゾーン $\left(\mathrm{P}_{54}\right)$ 即ち $\mathrm{C}_{2} \mathrm{H}_{5}-\mathrm{SO}_{2}\langle\ldots-\mathrm{CH}-\mathrm{N}-\mathrm{N}$ H-CS-NH ${ }_{2}$ の両者の優秀性が認められ, 前者は広く抗結 核剤として応用されつつむるが，後者は英国学派により 研究がつづけられ Spinks, Martin, Story, Young 及 び Hoggarth 等の実験により試験管内の抗菌力より, 生 体内の抗菌力は遥に優れて居り, 其の原因は本剤のみの 特長である血中濃度の超持続性に帰しで括る。

余は1950年夏以来本刱を大手するととを得て，重症結 核患者の数例に投与し，パスと其の効果を比較せんとし たが，当時の製鼡の不良子重大な原因では岁つたが，心 悸圥進が見しくなり, 或者は食思不振となり, 到底連用
は困難となり中止した。其の折の副作用の状況が Feldman のプロミンを結核に試みて失敗した経験の記録と 非常に似ているのに気付き，或は之を河に応用したら意 外の効果を見るのではなからうかと考えて，自発的に申 し出た 9 例の結節瀨患者に試み，1950年12月最初の投薬 を開始した。光田氏反応を㭘し，皮疹のスメーヤを作り 瀨菌の変化を追求することとした。との9例の患者は既 に 2 ケ年間プロミン治療をつづけた例が多く然し皮疹の 瀨菌は 2 例を除いて全部陽性であつた。内服をつづけさ せる裡 2 ケ月目に光田氏反応が陽転したり，急速に皮疹 の菌の消失を見たものもあり一時は警喜したが，副作用 として食思不振の訴が强くなり連用に困難ならしめた。 其処儿於て $\mathrm{P}_{54}$ を大風子油に眯濁して筋注すれば，其 の絶対投与量を減じ得るし，大風子油との相乗作用によ つて薬効を倍加し得るのではなかろうかと想像したので 懸濁液を作るとととした。当時大風子油の新しい手持品 がなく約 5 年以上経過した酸度の高いものであつたの で, 之を精製した処注射時完全に無痛であつた。最初 $\mathrm{P}_{54}$ $30 \mathrm{mg}$ pro 1c.c. としたが其後水溶性 $\mathrm{P}_{54}$ 其他エチルエス テル得摆液等十数種の製品を試作して試みたが完全に失 敗し, 最初の $\mathrm{P}_{54} \mathrm{~L}$ (30mg pro 1c.c.) が最良のものでめ るととも確認し得た。臨床実験については1951年4月第 24回日本顁学会に最初の報告を行い，其後追加報告をつ うけたが，現在迄最長 34ケ月，斑紋型 4 例，神経型15 例結節型40例について， $\mathrm{P}_{54} \mathrm{~L}$ 単独又はプロミンとの併 用による治験例を得たので，此処に一括して報告し，諸 家の叱正を俟つものでまる。

\section{実験方法}

最初試み大症例は第4,表結節瀨化示すNo.1 より No.9 まででめりプロミン注射 2 ケ年以上を施行して艏菌之 ならなかつた 7 例及び皮疹の菌検出不能の 2 例であり， 特に之等の患者は向後好転するであろうとの予想の許に 
でなく，患者の自由意志によつたので予作意して行か なかつた。

始めは内服によつた，一日量 $25 \mathrm{mg}$ 頓服 1 回宛 4 日間 連用，副作用がなければ $50 \mathrm{mg}$ に増量して 2 日間投与， 更に副作用がなければ 1 日量 $100 \mathrm{mg}$ として 3 回に分服 させた。No. 1 はよくたへて 5 ヶ月間に全量 $8.45 \mathrm{~g}$ を服 用して何等支障はなかつたが，其他の例に於ては食思不 振, 倦怠感, 胃炎等の訴をなするのがあつた。当時使用 した $P_{54}$ は可成不純で, 純度 $85 \%$ 位でむるととが後に 判明したが，原因は其の為であるかは不明でせる。然し 臨床的には皮疹のスメーヤでは瀨菌は可成急速に变性を 見せはじめたので有力な治癩効果を有するととは間違な く, 且抗酸性菌の特性として, 如何なる有力な抗菌性物 質が現れたとしても，それのみによつて全治するるので は決してなく，身体内の自然治蒸力との協力によるもの でむり，此の意味では漸減的に瀨菌の発育を疎止すべき で余り急激の効果を期待するととは適当でなく, 其のた めには少もく薬鄅を数ヶ年は作用させ得て且つ毒性を示 さないととを必要とする。その目的のために

1. $P_{54}$ は血中濃度の持続時間が長いので, 之を連用 した場合は其の使用量が可なり減量可能であろう。

2. 療養所の入園患者比対する心理的の影響からも注
射薬とする。但し静注等注射法が困難で忍つてはなら い。皮乃至筋注を適当とする。

3. 注射による硬結, 化膿, 疹痛等を皆無にする必要 が女る。

之の考え方から, 油性ペニシリンと同様に $\mathrm{P}_{54}$ を油に 䀣濁して筋注して見たらと溶媒に適当な油を考えて見 た。落花生油はかつて戦時中大風子油の輸大が杜絶しか かつた時, 代用品になるだろうとの予想の許に結節瀨の 患者に注射して急性浸潤を抢てさせて面目を失した苦い 経験がまるので, 油性ペニシリンの溶媒で步る落花生油 は最初から敬遠した。結局相乗作用もある等であるから と大風子油を溶媒に定めて眯濁液を作るとととした。 $\mathrm{P}_{54}$ は内服の場合の $1 / 3$ 量 $30 \mathrm{mg}$, 且油の䯚濁により恐ら く血中濃度を延長されるから隔日注射で可能であり大風 子油 1 c.c. に対して $P_{54} 30 \mathrm{mg}$ の眯濁液の使用で充分で めろらと考えた。

当時大風子油は戦時中大手したものしかなく，5年以 上経過し酸度が高く到底使用にたえなくなつたので之を 精製した処，非常に粘度の少い良い油を得られ，之を溶 媒として使用した。次に之を家乐慰筋内同一部位に週六 回四週間 1 c.c. 宛連続注射し硬結, 疼痛其他の副作用を 観察した。

第 1 表 $\mathrm{P}_{54} \mathrm{~L}$ 注射家雨体重の変化

\begin{tabular}{|c|c|c|c|c|c|c|c|c|c|}
\hline \multirow{2}{*}{ 家秋番号 } & \multirow{2}{*}{$\begin{array}{c}P_{54} \text { 注 } \\
\text { 射 量 }\end{array}$} & \multirow{2}{*}{ 注射期間 } & \multicolumn{6}{|c|}{ 家 雭 体 重 の 変 化 } & \multirow{2}{*}{$\mid \begin{array}{l}P_{54} \\
\text { Pro kilo }\end{array}$} \\
\hline & & & 最初 & 第一週 & 第二週 & 第三週 & 第四週 & 第五週 & \\
\hline 1 & $0.72 \mathrm{~g}$ & 28 日 & 3175 & 3180 & 3175 & 3170 & 3170 & 3170 & $9.5 \mathrm{mg}$ \\
\hline 2 & $0.72 \mathrm{~g}$ & 28 日 & 2775 & 2560 & 2570 & 2545 & 2535 & 2695 & $10.1 \mathrm{mg}$ \\
\hline 3 & $0.72 \mathrm{~g}$ & 28日 & 3125 & 3140 & 3240 & 3150 & 3070 & 3160 & $10.0 \mathrm{mg}$ \\
\hline 4 & $0.72 \mathrm{~g}$ & 28 日 & 3000 & 2890 & 3010 & 3020 & 2935 & 2900 & $10.0 \mathrm{mg}$ \\
\hline
\end{tabular}

表に示す通り第 2 例が急速儿体重減少を見多少食慾が 減じた外は殆んど支障なく, 局所の硬結は全然なく吸収 極めて可良で人体に応用しても何等结険のないととb確 められたので1951年 2 月第 3 表結節瀨の第 $2,4,63$ 例の 患者に始めて慰筋に 1 c.c. 宛注射した。溶媒が大風子油 であるから, 注射時も, 注射後も可成疼痛がめるであろら と覚悟した期待は裏切られ，全然舤痛であるので一同囁 然とした。注射後も硬結, 疼痛は全然なく第 2 及び第 3 の 目的は完全に達せられた。此の無痛の原因は大風子油の 精製によるか， $\mathrm{P}_{54}$ を䀣濁したためであるか疑問ですつ たので，精製大風子油を繁筋に注射して見たら矢張り無 痛で何等硬結を残さなかつたの(自家実験)で，此の精製 法により大風子油は完全に無痛になるととを確め得た。
無痛注射痽が得られたため其後症例の追加には極めて 好都合であつたが，㒖に $\mathrm{P}_{54} 30 \mathrm{mg}$ 週 $90 \mathrm{mg}$ の投与量で 果して何程の治瀨効果が得られるか疑問でまり, 大風子 油の演ずる役割が高いのではないかとも考えられたが， 皮疹のスメーヤの結果は従来大風子油単独療法の場合を 遥に超えて居た。 $\mathrm{P}_{54}$ による効果であるてとを実証する ためには血中濃度の測定を第一条件とするが Beckmann の Electro-Spectro Photometer を使用しなければ不可能 なので, 之を実験するてとが出来なかつた。こんな理由 で大風子油以外の殓媒を是非欲しかつたのでアルミニユ 一ム, モノステアレートを加えた水性眯濁液, ゼラチン 慙濁液, 其他の油を使用したもの等10数種の製剤を試み たが全部成功しなかつた。別の意味から大風子油エチル 
エステル懸濁液を試作したが，之についても所期の成績 は得られず，結局最初の $\mathrm{P}_{54}$ 以上の製剤恃作り得なかつ た。其後連用するに及んで貧血, 白血球減少, 尿中異常 物質の排淽，倦怘感等本剂によると思われる副作用は絶 無でめつたので $\mathrm{P}_{54}$ の絶対量の増加を考文 1 c.c. $60 \mathrm{mg}$

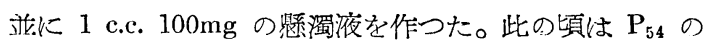
精製法も非常に進歩し純度も100\%に近いものが得られ たので照濁法に対して特種の装作を加えたから，最初は 失敗した 1 c.c. $60 \mathrm{mg}$ の㲘濁液は連用によつても何等硬 結疼痛なく成功し, 現在は強力 $\mathrm{P}_{54} \mathrm{~L}$ として使用して居 る。 $100 \mathrm{mg}$ 㲘濁液は個人差が強く, 全然無痛で連用可 能な例もむるし, 又多少硬結を残し, 注射後翌日中疼痛 を訴える例もむり目下一般には使用出来ない, 状沉にむ る。

本実験に当り大多数の患者の病年は 10 年以上できり， 大風子油, プロミン等の影響を受けて居り, 発病直ちに 本剤のみによつて治療した例は極めて僅しかない。然し 療養所に於ける経験上, 最初新薬が発表されると好奇心 から其の治療を希望する者が表れるが，其の效果は可成 正確に批判されて, 有効である場合は希望者は次々に增 加して来るものである。本剤も最初製版大手難から数を 可成制限して居たが，次第に希望者が増えて来て中止す る例は極めて少かつたので可成有効でめるととが褱書さ れた。其後浴奥助教授により, 結核菌による発育阻止試 験により大風子油との相乗作用が確認され, 谷 血助教 授, 両木学士により待望の血中濃度, 尿中排出試験の戊 樍を得られたので其の効果を確誋するととが出来た。

現在に於ける使用法は本剤単独の場合は, 0.5 c.c. 乃 至 1 c.c. 週三回臂筋注射を行ひ次第に增量して 3 c.c.
に及ぶか，又は強力 $\mathrm{P}_{54} \mathrm{~L} 2$ c.c. 迄にする。

プロミンとの併用の場合は， $\mathrm{P}_{54} \mathrm{~L}$ を前述の如く注射 し, プロミン 2.5c.c. 乃至 5 c.c. を週三回静注する。

結節瀕の場合は，楅性結節性紅斑発生-予防のためメチ オニン製哓であるバンチオニンを併用するととるある

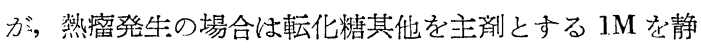
注し，消視末で本剤の治療は中止する。

神経鹤に於ては特性として彷血が多いがザーリー60 \%位に低下した場合はマスチゲン $\mathrm{B}_{12}$ を搠用する。

局所に対してはスプラーゼ（持田）又は八ロターゼ （武田）を持田単位 500 乃至2000を直接 $\mathrm{P}_{54} \mathrm{~L} 0.25$ 万至 0.5 c.c. に溶解して，結節の場合は結節内に，尺骨神経 痛等の訴の強い場合は肘部神経幹附近に深く注射する。 腓骨神経麻㿎の場合は脛骨角へ梁く注射する。回数は週 1 回とする。其の場命は全身潦法は平常の如く行う。

\section{臨床成績}

\section{1. 斑紋旗}

膓 2 表に示す通りであるが，第 1 例は本剂単独注射を 行い右耳款のみ隐性増琹様斑紋を生じて居たが連用 30 ヶ月で知覚脱も恢復し完全に皮疹杜消䘤し僅に尺骨神経 の肥厚が残る丈で治癒と判定し得る。第 2 例は病年子長 く最初他の療養所で治療を受けて可成好転して居たが知

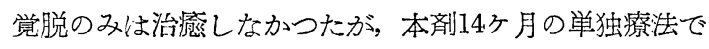
恢復皮疹の切片標本により治癒を確認した。第 3 例は発 病直ちに入院し（写真第 1 号参照）ヒドラジット 3 ケ月 投与恵化, 本剂単独療法経過順調である。第 4 例は妊娠 出産後增覀したもので（写真第 2 号参照）プロミンとの 併用療法により12ケ月で急速の治㽷を見せて居る。

第 2 表 斑 紋瀨

\begin{tabular}{|c|c|c|c|c|c|c|c|c|c|c|c|}
\hline \multirow{2}{*}{$\begin{array}{l}\text { 番 } \\
\text { 号 }\end{array}$} & \multirow{2}{*}{ 氏 名 } & \multirow{2}{*}{ 性 } & \multirow{2}{*}{$\begin{array}{l}\text { 年 } \\
\text { 令 }\end{array}$} & \multirow{2}{*}{$\begin{array}{l}\text { 初 } \\
\text { 発 }\end{array}$} & \multirow{2}{*}{$\begin{array}{l}\text { 病 } \\
\text { 年 }\end{array}$} & \multicolumn{2}{|c|}{$\mathrm{P}_{54} \mathrm{~L}$} & \multicolumn{2}{|c|}{ プロミン } & \multirow{2}{*}{ 治 } & \multirow{2}{*}{ 副 } \\
\hline & & & & & & 期 間 & 回数 & 期 間 & 回数 & & \\
\hline 1 & $\mathrm{O} \cdot \mathrm{K}$ & 우 & 23 & 20 & 3 & $\begin{array}{r}26 \text { 年 } 4 \text { 月 } \\
30 \text { ケ月 }\end{array}$ & 278 & - & - & 班紋消褪知覚脱恢復全治 & \\
\hline 2 & $\mathrm{~K} \cdot \mathrm{Y}$ & $\hat{o}$ & 32 & 24 & 9 & $\begin{array}{r}26 \text { 年 } 5 \text { 月 } \\
14 \text { 月 }\end{array}$ & 134 & - & - & 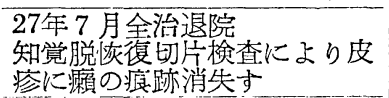 & \\
\hline 3 & M. T & $\hat{o}$ & 56 & 55 & 1 & $\begin{array}{r}27 \text { 年 } 7 \text { 月 } \\
14 \text { 月月 }\end{array}$ & 132 & - & - & 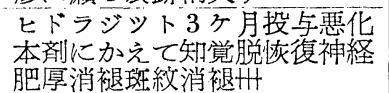 & 時に神経痛を批とす \\
\hline 4 & $\mathrm{H} \cdot \mathrm{K}$ & 우 & 28 & 22 & 6 & $\begin{array}{r}27 \text { 年.10月 } \\
12 \text { 月月 }\end{array}$ & 142 & $\begin{array}{r}27 \text { 年10月 } \\
12 \text { 月月 }\end{array}$ & 132 & $\begin{array}{l}\text { 斑紋浮腫消褪し僅に白斑を残 } \\
\mathrm{L} \text { 知賞脱を嚾に認められる神 } \\
\text { 経肥厚のみ残る }\end{array}$ & \\
\hline
\end{tabular}

\section{2. 神㳗瀨}

第 3 表に示す通りでめるが，第 2 例はスプラーゼ併用 により右脛骨に腓兴神経麻痺治療の目的で局所注射を行
つて居るが，最初は何等疼痛がなかつたが，次第に注射 時下肢に電馨性の疼痛を訴える様になり, 知覚脱の恢復

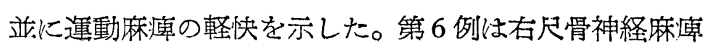


で握力右 17 左 20 であつたものがスプラーゼ仵用局所注射 33 回で, 右 21 左 20 と正常に恢復し, 環指小指の屈曲子治 り肘部知党脱を併つた皮疹の組織切片により浸潤其他の 像が消褪し，治療と認められたので退院させた。本例は プロミンにるよく耐えた。第11例は両側腓骨神経麻痺が

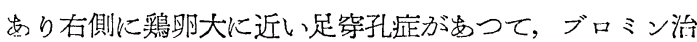
療では治癒しなかつたがギブス装着し，本郕単独浩潦 約 4r月後完全に治㽷し其後は再発を見ない。発汗部位 が増大したので夏季は可成過し良くなつた由である。第
12例は右第 1 掌骨間筋の菱縮が著明であるが，スブラー ゼの併用による局所注射により握力增加，筋菱縮の恢復 著明で全治したかと思われたが28年 9 月全身に激しい神 経痛が発生した。然し 2 ケ月後には殆しど治癒し，今迄 の例なら，乙んな激しい神経痛の場合は必ず猿手丈は鶚 爪手となるか，腓骨神経麻源を残すかで岁るが，本例の 場合は治癒後何等神経障碍は来さなかつだ。第13例子局 所注射30回で腓骨神経麻痻の軽快した例で心る。

第 3 表 神 経 顆

\begin{tabular}{|c|c|c|c|c|c|c|c|c|c|c|c|}
\hline \multirow{2}{*}{$\begin{array}{l}\text { 番 } \\
\text { 晃 }\end{array}$} & \multirow{2}{*}{ 氏名 性 } & \multirow{2}{*}{\multicolumn{2}{|c|}{$\begin{array}{l}\text { 年 } \\
\text { 令 }\end{array}$}} & \multirow{2}{*}{$\begin{array}{l}\text { 初 } \\
\text { 発 }\end{array}$} & \multirow{2}{*}{$\begin{array}{l}\text { 病 } \\
\text { 年 }\end{array}$} & \multicolumn{2}{|l|}{$\mathrm{P}_{54} \mathrm{~L}$} & \multicolumn{2}{|c|}{ プロミン } & \multirow{2}{*}{ 治 療 経 過 } & \multirow{2}{*}{ 副作 用 } \\
\hline & & & & & & 期 間 & 回数 & 期 間： & 回数 & & \\
\hline 1 & $\mathrm{~S} \cdot \mathrm{Y}$ & $3 \varepsilon$ & & 16 & 29 & \begin{tabular}{|l}
26 年 4 月 \\
29 肙
\end{tabular} & 348 & $\left|\begin{array}{|c|}24 \text { 年 } 10 \text { 月 } \\
48 \text { 肙 }\end{array}\right|$ & 23 & 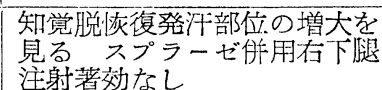 & 分血其他なし \\
\hline 2 & I. $\dot{\mathrm{K}}$ & 28 & & 23 & 5 & 闹上 & 317 & \begin{tabular}{|c|}
23 年11月 \\
58 肙
\end{tabular} & 170 & 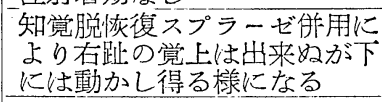 & 檚血其他なし \\
\hline 3 & $\mathrm{O} \cdot \mathrm{Y}$ & 69 & & 23 & 46 & $\begin{array}{r}26 \text { 年 } 5 \text { 月 } \\
28 \text { 肙 }\end{array}$ & 95 & \begin{tabular}{r|}
26 年 5 月 \\
28 只
\end{tabular} & 30 & 変化は認められぬ & 胃腸障碍の訴娄り \\
\hline 4 & $\mathrm{Y} \cdot \mathrm{F}$ & 41. & & 17 & 24 & $\begin{array}{r}26 \text { 年 } 4 \text { 月 } \\
22 \text { ケ月 }\end{array}$ & 256 & \begin{tabular}{|c|}
23 年11月 \\
58ヶ月
\end{tabular} & 428 & 知覚脱多少:恢復 & 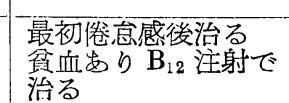 \\
\hline 5 & $\mathrm{~F} \cdot \mathrm{H}$ & 35 & & 28 & 7 & 同上 & 25 & \begin{tabular}{|c|}
24 年 $11 月$ \\
$46 ヶ$ 月
\end{tabular} & 138 & 著効を見ず & な \\
\hline 6 & $\mathrm{~A} \cdot \mathrm{K} \hat{\imath}$ & 16 & & 11 & 5 & $\begin{array}{l}\text { 同上 } \\
23 \text { ケ月 }\end{array}$ & 192 & $\begin{array}{r}24 \text { 年 } 6 \text { 月 } \\
57 \text { ケ月 }\end{array}$ & 710 & 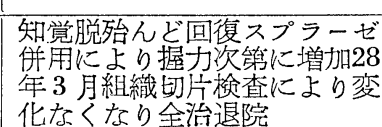 & なし \\
\hline 7 & $\mathrm{~S} \cdot \mathrm{T}$ & 25 & & 19 & 6 & $\begin{array}{l}\text { 同上 } \\
29 \text { ケ月 }\end{array}$ & 304 & \begin{tabular}{|r|}
27 年 11 月 \\
58 ケ月
\end{tabular} & 582 & $\begin{array}{l}\text { スプラーゼ併用により驚片手 } \\
\text { の軽度の回復を見る }\end{array}$ & 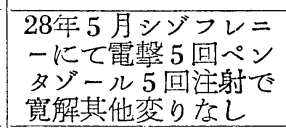 \\
\hline 8 & S. & 57 & & 7 & 50 & 阙上 & 285 & $\mid$\begin{tabular}{r|}
25 年 5 月 \\
40 肙
\end{tabular} & 261 & 著効な & 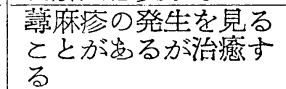 \\
\hline 9 & M. U & 60 & & 30 & 30 & 同上 & 344 & $\left|\begin{array}{|}24 \text { 年11月 } \\
46 \text { 命 }\end{array}\right|$ & 342 & 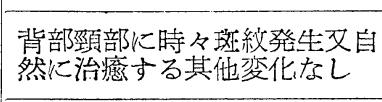 & $\begin{array}{l}\text { 高血压焉る } \\
\text { の関係はな } \\
\text { る }\end{array}$ \\
\hline 10 & $\mathrm{Y} \cdot \mathrm{M}$ & 42 & & 27 & 15 & 同上 & 115 & $\mid \begin{array}{r}25 \text { 年 } 5 \text { 月 } \\
40 \text { ケ月 }\end{array}$ & 220 & 藷変なし & なし \\
\hline 11 & I. $\mathrm{D}$ & 52 & & 35 & 17 & 同上 & 145 & $\left|\begin{array}{r}25 \text { 年 } 4 \text { 冝 } \\
39 \text { 员 }\end{array}\right|$ & 204 & 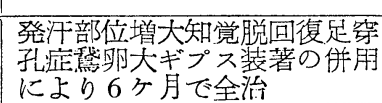 & 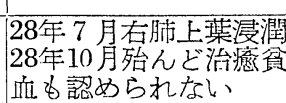 \\
\hline 12 & $\mathrm{~S} \cdot \mathrm{M}$ & 25 & & 18 & 7 & $\begin{array}{l}\text { 同上 } \\
29 \text { ケ月 }\end{array}$ & 295 & $\begin{array}{r}26 \text { 年 } 8 \text { 月 } \\
35 \text { ヶ月 }\end{array}$ & 154 & 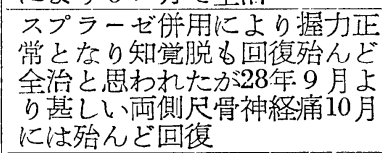 & 檚血其他なし \\
\hline 13 & $\mathrm{Y} \cdot \mathrm{Y}$ & 43 & & 28 & 15 & $\begin{array}{r}26 \text { 年 } 4 \text { 月 } \\
29 \text { 肙 }\end{array}$ & 332 & $\begin{array}{r}24 \text { 年 } 10 \text { 月 } \\
40 \text { ケ月 }\end{array}$ & 210 & $\begin{array}{l}\text { スプラーゼの併用により腓骨 } \\
\text { 神経麻瘟の回復が認められた } \\
\text { 発汗部位増大 }\end{array}$ & $\begin{array}{l}\text { 多少侕血が先り } \\
\text { に注射で恢復 }\end{array}$ \\
\hline 14 & K. S & 67 & & 7 & 60 & $\begin{array}{r}27 \text { 年 } 7 \text { 月 } \\
\text { 14ケ月 }\end{array}$ & 198 & \begin{tabular}{r|}
27 年 7 月 \\
14 多月
\end{tabular} & 173 & 変化を認められない & なし \\
\hline 15 & T. E & 5] & & 51 & 6 & $\begin{array}{r}27 \text { 年 } 9 \text { 月 } \\
12 \text { ケ月 }\end{array}$ & 116 & $\begin{array}{r}27 \text { 年 } 9 \text { 月 } \\
12 \text { 肙: }\end{array}$ & 69 & 著変なし & なし \\
\hline
\end{tabular}


以上の如く, 神経瀨の場合はスブラーゼの併用による 局所注射が，可成成樍を挙げて招り，一般状態としては 発汗部位の増大が認められる。何れの薬㓮でも同じ様 に，神経顸借対する効果は余り著明でない。足穿孔症が 有空ギプス装置と本郕注射のみで相当大きなるのが割合 短時間に治瘾した経験は，万年傷として患者を多年苦し めて来たもの丈に非常に興味樑い, 従前万年傷治療の目 的でプロ ミンを再三動脈注射して成功しなかつた経験か ら本剤は特に支配神経作用して其の治癋を促進させる ものであるまいかと思はれる。

\section{3. 結節颠}

第 1 例は 23 年 11 月以来 2 ケ年間にブロミン 497 回注射 したが，皮疹の菌は陽性であり，光田氏反忍も陰性であ

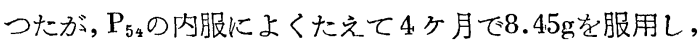
其の後は注射を行つたが，8 月で皮疹の菌陰性となり 10ヶ月目に光田反忍は陽性になつたが，覜性パンヌスは 消褂しない。第 2 例は 2 ケ年間にブロミン439回の注射を 行つたが皮蓼の菌斗, 其後 $\mathrm{P}_{54} \mathrm{~L}$ 及び内服により 4 ヶ月目 に光田反応H，然し皮疹からは菌が認められたが11ヶ月 目に菌陰性となつた。内服 2 ケ間 $3.35 \mathrm{~g}$ を投与したが 副作用のために連用不能となつた。第 3 例は入院後 6 ヶ

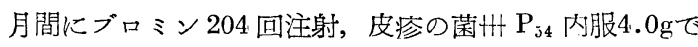
光田氏反忘一皮疹の菌はH, 其後は $\mathrm{P}_{54} \mathrm{~L}$ 注射のみで 26 年 3 月光田反応开, 皮疹の菌は 28 年 2 月陰性となる。（写 真第 3 参照）第 4 例は 2 年間のプロミン注射でも菌㓌性 とならなかつたが， $\mathrm{P}_{54} \mathrm{~L}$ の注射（内服 $\mathrm{P}_{54} 3.4 \mathrm{~g}$ ) 4 ケ 月で光田氏反応陽転 3 ヶ年後菌陰性となり, 頭髪眉毛も 再生を見せつつまむる。（写真第 4 号）第 8 例 2 ケ年間 ヒブロミン 455 回注射を行つたが, 菌は陽性, 其後ブロ ミンを中止し, 本䬉の内服其後注射に切りかへ, 光田反 心は10ヶ月目に陽転，其間急性浸潤が主として顔面に発 生したが，間もなく消螁し1ヶ年 4 ケ月で菌陰性とな り， 2 年目皮疮の切片標本で治瘾を確認した。眉毛は完 全に脱落していたが，可成著明に再生を認められた。(写 真第 5 号）。第 12 例はブロミンも良く耐えて 2 ケ年間に 838 回（一日二回注射の場合もある）注射したが菌は陰 性とならず $\mathrm{P}_{54} \mathrm{~L}$ 注射にかえて 1 ケ年後菌陰性, 光田氏 反応も陽転した。此の例では $\mathrm{P}_{54} \mathrm{~L} 60 \mathrm{mg}$ pro 1 c.c. から $100 \mathrm{mg}$ pro 1 c.c. を使用し, 一日量 $200 \mathrm{mg}\left(\mathrm{P}_{54}\right)$ に及 しだが著明の副作用を認めなかつた。第17例は $\mathrm{P}_{54} \mathrm{~L}$ 注 射開始後約 1 ケ年で菌は陰性になつたが，一般症状も良 く，結節性紅斑の発生も1 1 年以上見ないにもかかわら ず光田氏反芯は 1 ケ年以上皮疮の菌を詔めないのに陽転 しない。第19例は異常体質がある様でブロミン 5 c.c. の
静注は出来ず 2.5 c.c. に20\%葡萄糖を加え.て極めて除々 に注射して辛らじて附兄られるが， $\mathrm{P}_{54} \mathrm{~L}$ の場合も 1 c.c. の注射により, 心悸立進があり一回 0.25c.c. でやつと連 用が出来た例でもるが，皮疹の菌は增加したり，減少し たり, 再び增加したりして效果は認められぬ, 然るに光 田氏反心は $\mathrm{P}_{54} \mathrm{~L}$ 注射開始後 5 ケ月目で陽転しかかつた 珍らしい例でめる。第20例は玟紋で初発し爾来決して治 療を行わず，漁業に彷事していたが，急速に琹化して結 節が発生し，浿㾤となり人院治潦をやつと肯んじたが $\mathrm{P}_{54} \mathrm{~L}$ でのみ治療し, 溃堭の治瘾子著明で, 皮疹の菌も 可成退行变性を示して来た其の間僅に49回 (4万月間) の注射を行つた丈でむる。其後家庭の事情で逃走した。

(写真第 6 号) 第21例はブロミンにより菌陰性となつた が，光田氏反心は陽転せず， $P_{54} \mathrm{~L}$ 併用により直ちに陽 転し，其後眉毛の再生著明で殆んぞ正常に恢復した。此 の例は魚鯧源を併発して居つたので，牛脳下垂体埋没療 法を三回 (冷凍法) 行ひ, 魚䮈傍は軽快して居るが此の 影響により眉毛の再生が著明である様である。第24例は 12年前初発し，大風子油注射で結節は完全に吸収したも のが 3 年前より再登した例で最初 $P_{54} \mathrm{~L}$ のみで治療し, 著明に結節の低下吸収を認め, 局所にはスブラーゼ併用 による注射を行つた。一ケ年後約 2 ケ月間一時帰省し増 琹して䚻園したが，此の時背部の局所注射を行つた結節 のみは再発を見ず吸収した樭であり，其他の部分は全部 琹化して居た。其後ブロミンとの併用により，次第に軽 快し光田氏反心す 1 ヶ年後には陽伝し結節も殆んど吸収 し，没疹の菌は殆んど認められない。（写真第 7 号）第 25例はブロミンとの併用療法で岁るが，2 2 年で菌陰性 ，光田氏反忘も陽転したが，腎炎を併発した主としてビ タミン B 50mg 乃至 100mg の皮注により可成重症でめ つた本症を治痛し得た。盾毛再生著明でめり，其後従前 通りブロミン併用注射を半ヶ年以上もつづけて居るが腎 炎の発生は見ない。第28例は極めて軽度の浸潤型でむり 自宅で大風子油の内服をつづけて居つた丈で皮疹の菌は 認められない状態で，眉毛脱落を主訴として大院した例 でめるが， $P_{54} \mathrm{~L}$ 単独療法 14 ケ月其後ブロミン併用療法 により眉毛の再生は著明でめる其の間下垂体埋没を行つ た。28年10月頃より顔面に瀨性黄色瞳を発生後瀨菌の完 全な脂肪変性が認められる。第29例は12年前初発一時軽 快したが 3 年前より再発愍化したもので，最初ブロミン 併用潦法を行つたが副作用のため中止 $\mathrm{P}_{54} \mathrm{~L}$ 単独篁法で， 結節级収著明，皮疹の菌は退行变性を示して居る。第 29例は初発当時大風子油注射で一応治癒し其後再発した 
ものである。33ケ月間に $\mathrm{P}_{54} \mathrm{~L}$ 147本, ブロミンは副作用 で28本注射し其後中止したが結節の吸収は著明で岁る。

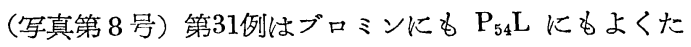
えて15ヶ月間の注射で皮疹の菌は陰性となり，目下時々 熱瘤の発生を見つつむる。(写真第 9 号)第33例は眉毛の 脱落を見ない結節瀨でまり,皮疹の菌は強陽性でめつた。 オーストリヤで発病し，内地に送還されたものでせる。 ブロミンは殆んど併用せず， $\mathrm{P}_{54} \mathrm{~L}$ のみで治療を行つた。 約 1 ケ年で皮疹の菌陰性となり, 結節の吸収落明, 知覚 脱の恢復も著しい。(写真第10号) 第34例は六年前初発, 信仰によつて全然治療せず，入園時熱瘤を発生して居た 例であるが， $\mathrm{P}_{54} \mathrm{~L}$ 17ケ月間比 127 回最初 1 c.c. より 3c.c. 迄に增量した。ブロミンは副作用により殆んど注射せ ず，経過を観察したが，結節吸収，潰壕の洁瘾は著明で める。（写真第11号）第35例は娘か瀨で逆伝染である。 4. 年前初発, 顔面頸部等の浸潤部えスプラーゼ併用の局 所注射を週一回宛行つて皮疹の消褪は可成著明となり， 菌も8ケ月間で可成退行変性を見せて，皮疹からは殆ん ど見出せ埕に軽快して居る。プロミン併用療法を行つ て居る。(写真第12号) 第36例はプロミンで菌の陰転を 見せなかつたが $\mathrm{P}_{54} \mathrm{~L} 2$ ケ月注射で皮疮の菌は起しい減 少を認めた（写真第13号）第38例は24年前の初発で眉毛 脱落し, 顔面其他に浸潤がある。ブロミンにも $\mathrm{P}_{54} \mathrm{~L}$ に
も可成過敏で入院後強力な治療が行えなかつたが，3

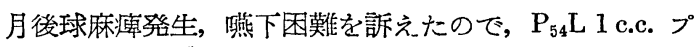
ロミン 5 c.c. を20\%葡萄糖を加えて静注をつつけたらよ くたえて次第に軽快しつつある。光田氏反応を検すると 強陽性で岁り，皮疹の菌は陰性で岕つた。

以上の如く結節簀に於ては早い場合は 1 ケ年遅くても 大体 2 ケ年で菌は陰性となり，プロミンの併用の場合 は, 急性の症状を呈して居るものでは効果は著明である が,慢性の状況を呈して居るものでは,プロミンの影響は 余り認められない。光田氏反応は陽転しても皮疹の菌の 証明される例もあるが，遠からず皮疹の菌は見出されな くなる。菌除性となつても熱瘤の発生を時々見るが1ケ 年程すると熱瘤も、全然発生しなくなり,顔面に著明な, 癩 性黄色腫の発生を見る。眉毛の再生する例も耊るが，余 り著明に再生しないるのも方。何れにしても眉毛の発 生は可成俉められる。知覚脱の恢復其他も明でめる。 プロミン例用によつても格別に貧血を抢てさない。同時 に割合にプロミンによる倦念感, 脱力感がないので日常 の学働には殆んど影響はない。神経痛の訴はプロミン単 独療法時代よりる激減して居る。副作用として腎炎を 1 例に見， 2 例に黄胆の発生を見たがはたして，本療法に 原因するかは不明でめる。

第 4 表 結 節 顆

\begin{tabular}{|c|c|c|c|c|c|c|c|c|c|c|c|c|}
\hline \multirow{2}{*}{ 番 } & \multirow{2}{*}{ 氏 名 } & \multirow{2}{*}{\multicolumn{2}{|c|}{$\begin{array}{l}\text { 年初病 } \\
\text { 令| }\end{array}$}} & \multicolumn{2}{|l|}{$\mathrm{P}_{54} \mathrm{~L}$} & \multicolumn{2}{|c|}{ プロミン } & 治 & 療 & 経 & \multirow{2}{*}{ 副 作 用 } & \multirow{2}{*}{ 備 考 } \\
\hline & & & & 期 間 四 & 回数 & 期 & 回数 & 菌 & 光田氏反応 & 症 状 の変化 & & \\
\hline 1 & M. N & $\hat{s} 3$ & $1421^{\prime}$ & \begin{tabular}{|}
25 年11月 \\
34 ケ
\end{tabular} & $345^{2}$ & \begin{tabular}{|r|} 
23年11月 \\
58ヶ
\end{tabular} & 671 & $\begin{array}{l}25 \text { 年11月世 } \\
26 \text { 年 } 7 \text { 月一 }\end{array}$ & $\begin{array}{l}+\mid 25 \text { 年 } 12 \text { 月 } \\
-26 \text { 年 } 6 \text { 月H }\end{array} \mid$ & \begin{tabular}{|}
$\mid$ 眉毛の再生を見る眼の \\
|゚ンヌスは治らない
\end{tabular} & な & \begin{tabular}{|l}
$\mid$ 内服 \\
102 回 \\
$8.45 \mathrm{~g}$
\end{tabular} \\
\hline 2 & $\mathrm{~K} \cdot \mathrm{M}$ ? & +3 & $1713^{2}$ & $\begin{array}{r}25 \text { 年12月 } \\
33 \text { 合 }\end{array}$ & $348^{2}$ & 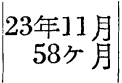 & 447 & $\begin{array}{l}25 \text { 年 } 12 \text { 月 }+ \\
26 \text { 年 } 10 \text { 月一 }\end{array}$ & $+\left|\begin{array}{l}25 \text { 年 } 12 \text { 月 } \\
26 \text { 年 } 3 \text { 月州 }\end{array}\right|$ & 眉毛再生士 & 薵麻疹 & $\mid \begin{array}{c}\text { 内服 } 47 \text { 回 } \\
3.35 \mathrm{~g}\end{array}$ \\
\hline 3 & H. T & o & & $\begin{array}{r}25 \text { 年12月 } \\
33 \text { 只 }\end{array}$ & $|389|^{2}$ & | 25 年 7 月 & 225 & $; \begin{array}{l}25 \text { 年 } 11 \text { 月 }+1+ \\
28 \text { 年 } 2 \text { 月一 }\end{array}$ & $\begin{array}{l}-125 \text { 年 } 12 \text { 月一 } \\
27 \text { 年 } 3 \text { 月H }\end{array}$ & \begin{tabular}{|l} 
結節吸収視力恢復 \\
知賞恢復
\end{tabular} & 多少坌血と & \begin{tabular}{|c|} 
内服 56 回 \\
$4.0 \mathrm{~g}$
\end{tabular} \\
\hline 4 & K. E & $\hat{\delta}$ & $3713^{2}$ & \begin{tabular}{|r|}
25 年 12 月 \\
33 肙
\end{tabular} & $403^{2}$ & 23年11月 & 268 & $\begin{array}{l}25 \text { 年 } 11 \text { 月 }+1 \\
28 \text { 年 } 9 \text { 月一 }\end{array}$ & $\begin{array}{l}H 25 \text { 年11月十 } \\
-26 \text { 年 } 3 \text { 月H }\end{array}$ & 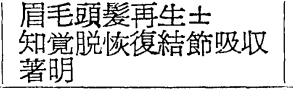 & な & \begin{tabular}{|c} 
内服 42 回 \\
$3.4 \mathrm{~g}$
\end{tabular} \\
\hline 5 & S.G & $\hat{\delta}$ & $1810^{2}$ & $\begin{array}{r}25 \text { 年12月 } \\
13 \text { 多 }\end{array}$ & 78 & - & 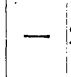 & 2 & $-\mid \begin{array}{l}25 \text { 年 } 12 \text { 月十 } \\
26 \text { 年 } 3 \text { 月廿一 }\end{array}$ & $\begin{array}{l}27 \text { 年 } 2 \text { 月退院 } \\
\text { 置毛再生知覚脱恢復 }\end{array}$ & な & $\begin{array}{c}\text { 内服52回 } \\
4.8 \mathrm{~g}\end{array}$ \\
\hline 6 & S.S & $\hat{o}$ & $148^{2}$ & $\begin{array}{l}\text { 5年11月! } \\
26 \text { 万月! }\end{array}$ & $1102^{2}$ & $\begin{array}{r}23 \text { 年 } 11 \text { 月 } \\
50 \text { 员 }\end{array}$ & 312 & $\begin{array}{l}25 \text { 年 } 12 \text { 月Ht } \\
26 \text { 年 } 3 \text { 月土 }\end{array}$ & 25 年 1 & 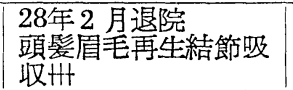 & は & \begin{tabular}{|l} 
内服84国 \\
$5.5 \mathrm{~g}$
\end{tabular} \\
\hline $7 \mid$ & U.R & o: & $286^{2}$ & $\begin{array}{r}26 \text { 年11月 } \\
34 \text { 员 }\end{array}$ & $354^{2}$ & \begin{tabular}{|r|} 
23年11月 \\
58ケ角
\end{tabular} & 574 & $\begin{array}{l}25 \text { 年 } 12 \text { 月 }+H+1 \\
27 \text { 年 } 3 \text { 月一 }\end{array}$ & \begin{tabular}{|l|}
$H+25$ 年 12 月 \\
-26 年 3 月 $H+H$
\end{tabular} & 覆毛再生十知覚脱恢 & な & $\begin{array}{l}\text { 股 } \\
\text { 119回 } \\
6.55 \mathrm{~g}\end{array}$ \\
\hline 8 & S.S & 600 & $50.10^{2}$ & \begin{tabular}{r|}
25 年 12 月 \\
33 员
\end{tabular} & $335^{2}$ & \begin{tabular}{|r|}
23 年11月 \\
58ケ
\end{tabular} & 614 & $\begin{array}{l}25 \text { 年 } 12 \text { 月 }+1 \\
27 \text { 年 } 3 \text { 月一 }\end{array}$ & $\begin{array}{l}H 25 \text { 年11月一 } \\
-26 \text { 年 } 9 \text { 月 } \mathrm{H}\end{array}$ & 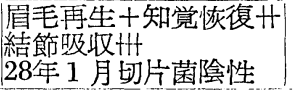 & な & $\begin{aligned} \text { 内服 } \\
2.8\end{aligned}$ \\
\hline
\end{tabular}




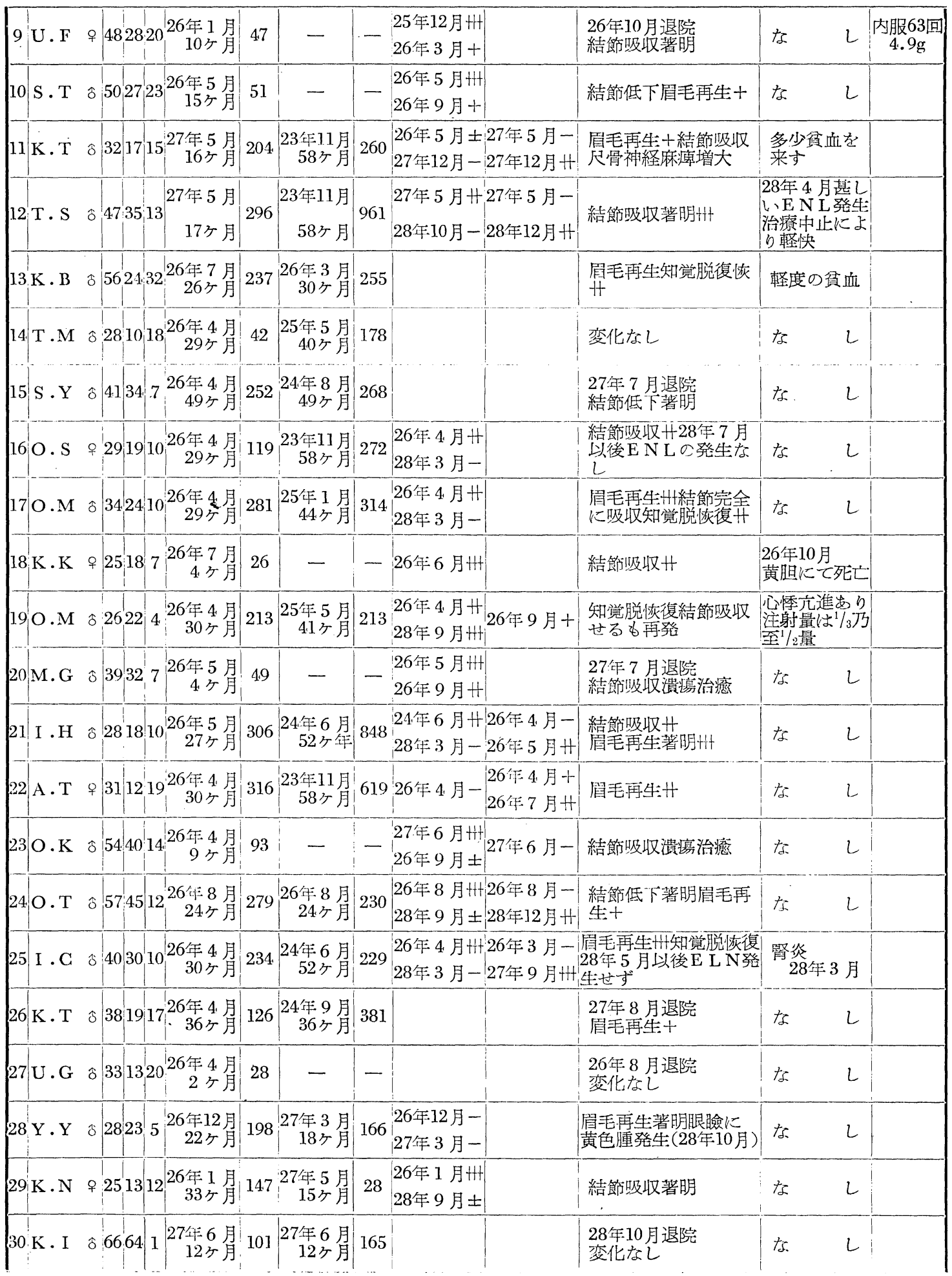




\begin{tabular}{|c|c|c|c|c|c|c|c|c|c|c|c|c|c|c|}
\hline 31 & A.T $\hat{\delta}$ & 31 & 1912 & 2 & $\begin{array}{l}\text { 年 } 7 \text { 月 } \\
14 \text { 多月 }\end{array}$ & 168 & $\left|\begin{array}{r}27 \text { 年 } 7 \text { 月 } \\
14 \text { 月月 }\end{array}\right|$ & 169 & $\left|\begin{array}{l}27 \text { 年 } 7 \text { 月H+ } \\
28 \text { 年10月一 }\end{array}\right|$ & & 結節吸収Ht & \multicolumn{2}{|c|}{ 多少貧血 } & \\
\hline 32 & $\mathrm{~S} . \mathrm{T} \quad \hat{o}$ & 20 & 173 & & $\begin{array}{l}\text { 年 } 4 \text { 月 } \\
17 \text { 月 }\end{array}$ & 168 & $\begin{array}{r}27 \text { 年 } 4 \text { 月 } \\
17 \text { ケ月 }\end{array}$ & 168 & & & 浸潤消褪圆毛再生泋 & な & $L$ & \\
\hline 33 & $\mathrm{H} . \mathrm{Y} \hat{\delta}$ & 22 & $\begin{array}{ll}21 & 1\end{array}$ & & $\begin{array}{l}\text { 年 } 7 \text { 月 } \\
14 \text { 月月 }\end{array}$ & 157 & $\left|\begin{array}{r}27 \text { 年 } 7 \text { 月 } \\
14 \text { 月月 }\end{array}\right|$ & 32 & 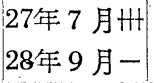 & & $\begin{array}{l}\text { 結節吸収H+t } \\
\text { 知覚脱恢復H }\end{array}$ & な & L & \\
\hline 34 & $\mathrm{~S} \cdot \mathrm{J} \quad \widehat{s}$ & 27 & \begin{tabular}{l|l}
31 & 6
\end{tabular} & 27 & $\begin{array}{l}\text { 年 } 7 \text { 月 } \\
14 \text { 方 }\end{array}$ & 127 & \begin{tabular}{|r|}
27 年 7 月 \\
14ケ月
\end{tabular} & 47 & $\left|\begin{array}{ll}27 \text { 年 } 7 \text { 月H+t } \\
25 \text { 年 } 9 \text { 月 } H+t \mid\end{array}\right|$ & & 結節吸収 Htt & な & L & \\
\hline 35 & $\mathrm{O} . \mathrm{H} \hat{\delta}$ & 68 & 644 & & $\begin{array}{r}3 \text { 年 } 2 \text { 月 } \\
8 \text { ケ月 }\end{array}$ & 85 & $\left|\begin{array}{rr}28 \text { 年 } 2 & \text { 月 } \\
8 & \text { ケ }\end{array}\right|$ & 67 & $\mid \begin{array}{l}28 \text { 年 } 2 \text { 月 } t+t \mid \\
28 \text { 年 } 12 \text { 月土 }\end{array}$ & & $\begin{array}{l}\text { 結節吸収协 } \\
\text { スプラーゼ併用 }\end{array}$ & な & L & \\
\hline 36 & E.S & 29 & 1811 & & $\begin{array}{l}3 \text { 年 } 7 \text { 月 } \\
2 \text { ケ月 }\end{array}$ & 25 & 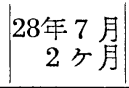 & 18 & $\begin{array}{l}28 \text { 年 } 7 \text { 月H } \\
28 \text { 年11月士 }\end{array}$ & & 結節多少吸収 & な & L & \\
\hline 37 & $\mathrm{~K} \cdot \mathrm{K} \quad \hat{\mathrm{o}}$ & $\$ 24$ & 195 & & $\begin{array}{l}\text { 年 } 6 \text { 月 } \\
3 \text { ケ月 }\end{array}$ & 42 & - & - & & & 浸潤消褪著明 & な & L & \\
\hline 38 & $\mathrm{~K} . \mathrm{H}$ & 37 & 1324 & & $\begin{array}{l}\text { 年 } 4 \text { 月 } \\
5 \text { ケ月 }\end{array}$ & 50 & $\mid \begin{array}{r}28 \text { 挐 } 4 \text { 月 } \\
5 \text { ケ月 }\end{array}$ & 24 & & 28年12月ttt & $\begin{array}{l}\text { 28年 } 8 \text { 月より球麻湶 } \\
\text { を招こす強力に注射 } \\
\text { しはじめたら軗快 }\end{array}$ & な & L. & \\
\hline 39 & M.K ô & 550 & 1535 & $5^{27}$ & $\begin{array}{l}\text { 年 } 3 \text { 月 } \\
18 \text { 月月 }\end{array}$ & 216 & \begin{tabular}{|}
27 年 3 月 \\
18 月
\end{tabular} & 151 & 27 年 3 月一 & & 浸潤吸収を見る & な & L & \\
\hline 40 & M.Y ô & 2 & 1511 & $1^{28}$ & $\begin{array}{r}\text { 年 } 4 \text { 月 } \\
5 \text { ケ月 } \\
\end{array}$ & 45 & - & 一 & \begin{tabular}{|l|}
28 年 3 月H \\
28 年 11 月土
\end{tabular} & & $\begin{array}{l}\text { 注射一月後関節炎で } \\
\text { 云以来漫潤消褪し } \\
\text { はじめる }\end{array}$ & な & L & \\
\hline
\end{tabular}

\section{考按}

$P_{54} \mathrm{~L}$ の治効機転に関しては, 津田氏試薬により血中濃 度, 譼器濃度を検するととが出来ず, Beckmanの Spector Photo meter を使用しなけば解らないので此の点実験に 因難を来したが浴奥助教授並に画木学二上の協闹研究によ り Spinks の発表した文献と大体一致した結果を得た。 又一方谷奥助教授は人型並島型結核菌に於て $\mathrm{P}_{54} \mathrm{~L}$ 単独 より $\mathrm{P}_{54} \mathrm{~L}$ は約30倍の抗菌力を有するととを実証した。 田底博士は， $\mathrm{P}_{54} \mathrm{~L}$ 単独治療 10 ケ月の結節濑の皮瘆の菌 を蓝光顕微鏡で追求し，瀬菌の退行変性を来すととを夹 証した。Francis 及び Spinks はテイビオンと $\mathrm{P}_{54} \mathrm{~L}$ の 血中濃度亚に淢器濃度を比較検討して遥に後者は前者心 優り，吸収は稍幄れるが，吸収は完全であり且遥に持続 的なととを笑証して居る。

以上の結果から見て $\mathrm{P}_{54} \mathrm{~L}$ の注射は每日の必要はなく 隔日又侮三日で有効で多り，特に増量してる，比例的 に血中濃度は上昇しないのて 1 回最大 3 c.c. を限度にす ベきでめろら。

プロミン併用により著効を見せた例を経験したが，過 去三ヶ年間プロミン単独療法時代の毎日静注法はやめ て, 隔日に静注して居る。プロミンの急速な血中濃度上 舁による病巣の刺战療法の効果を期待したもので，之は 目的を達して居ると思われる。結核に於いてパスとスト
マイの併用療法を行つたに等しいのではあるまいか。ス トマイの連用による抵抗囷の発生及び其他の副作用も, 關歇的にパスとの併用によつて, 長期連用が可能にな る。僧用療法とそ慢性疾患を治忿に導く最良の方法と思 われる。即ち $\mathrm{P}_{54} \mathrm{~L}$ とプロミンの隔日使用により，プロ ミン単独治療時代に生じた攸血, 脱力感其他の支障を殆 んぞ認めず, 治効速度も遥に早い。（之は皮疹の菌の追 求で寒証せられる。)

最近ヒアルロニターゼの製戍スプラーゼ又はハロター ゼを $\mathrm{P}_{54} \mathrm{~L}$ に直接浴解して 0.25 万至 0.5c.c. 宛を尺骨神 経の附近に注射して神経肥厚の消眞を見つつまる。之に より持続的に苦しんだ神経痛の全治した例も出る。又運 動麻疩の恢復した例子多る。本剤が特に神経親和性を有 ナるかは不明であるが，一般にプロミン単独治療時代よ りも神経痛の訴のなくなつたことは特筆すべき事契でせ る。之等の点に関して閔器濃度測定の問題が解決出来れ ば良いが，目下の状沉ては殆んど不可能であろう。

ヒアルロニダーゼとの阙用により結節の吸収も著明に 認められて居り，局所に直接有効に作用することは明で むる。

貧血，倦忠感，胃腸障害，腎炎，肝炎其他考えられる 副作用に就てはた守ず注意して，観祭したが著しいもの は見ら玌かつた。 


\section{結語}

1. 1950年12月以来現在迄最初は $\mathrm{P}_{54} \mathrm{~L}$ の内服, 1951 年 3 月以後は $\mathrm{P}_{54} \mathrm{~L}$ の注射により, 斑紋型 4 例, 神経型 15例，結節型40例の癩患者に念用して其の結果を報告し た。（プロミン併用例的含寺）

2. 班紋型に於ては大異 1 ケ年で著明に斑紋の消煺を 認められ，知賞脱の恢復为認められた。

3. 神経型に於ては著效を認め難いが，ヒアルロニダ

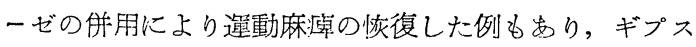
併用により足穿孔遮の完全に治癒した例がある。

4. 結節型に於ては皮捡の瀨菌の消褪は可成著明でせ り, 菌の退行変性を見, 皮疹に癩性黄色腫を発生し, 光 时氏反心は陽転し，遂には熱瘤の発生を全然見なくな

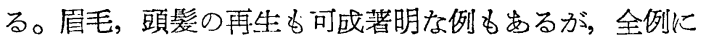
於て眉毛の再生は認められた。

5. 副作用は殆んど認められぬ。

6. $\mathrm{P}_{54} \mathrm{~L}$ 週三回，ブロミン週三回の併用療法は，プ ロミンの副作用を防止し，結核に於けるパス，ストマイ 併用療法に匹敵する効果を挙げ得る様でもる。

7. 詳細な治効機転は $\mathrm{P}_{54} \mathrm{~L}$ の血中謴度, 擮器濃度の 測定が非常に困難なので判明しない。

\section{文献省略}

（本砳究に対して， $\mathrm{P}_{54}$ 亚に $\mathrm{P}_{54} \mathrm{~L}$ 製㓩については森 永薬品白川支配人, 比良野薬学博士, 两木学士の援助心 よる処が多く, 種々助言を賜つた谷奥助教授並に進んで 人体実験を引き受けて頂いた身延梁敬園大園者諸君に深 く謝意を表する。） 
早田論艾附図 (1)

PLATE 1 斑緅型第 3 例

(27. 8. 27)

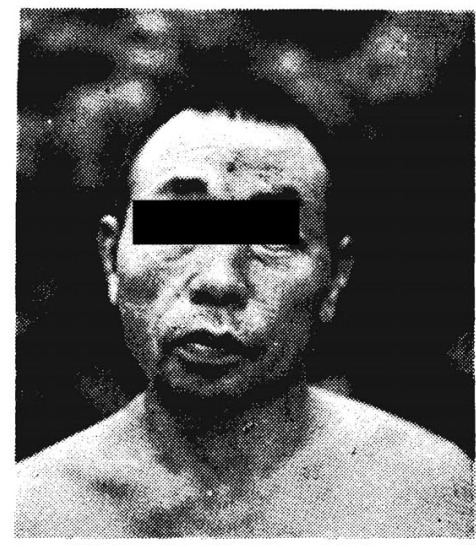

PLATE 2

(27. 10. 15)

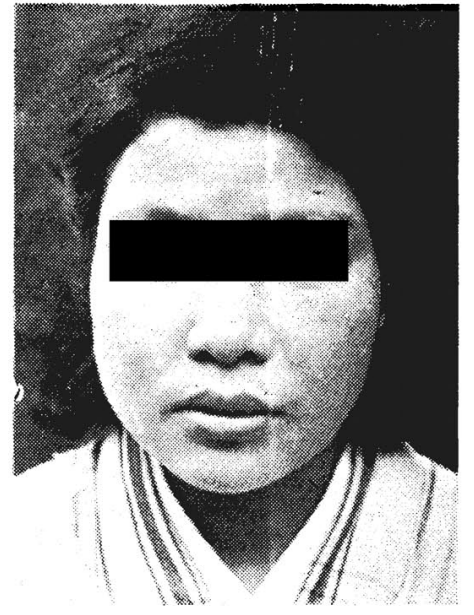

(26. 5. 21)

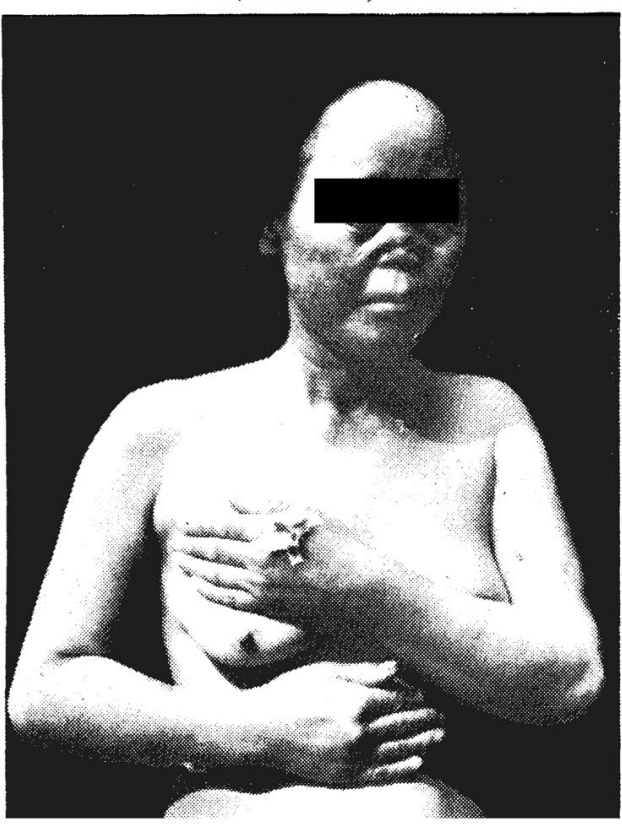

(28. 6. 26)

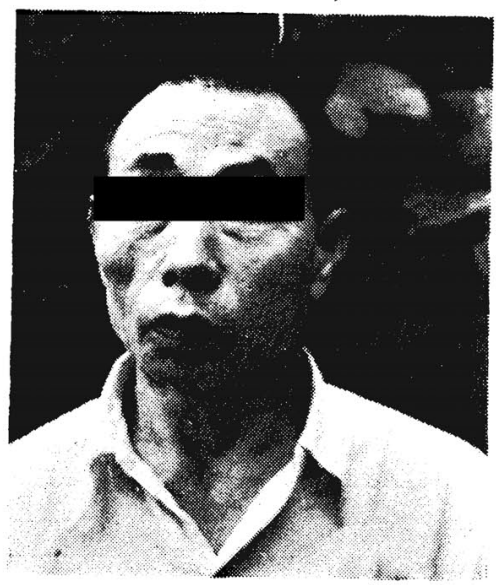

斑 紇 型第 4. 例

(28. 10. 27)

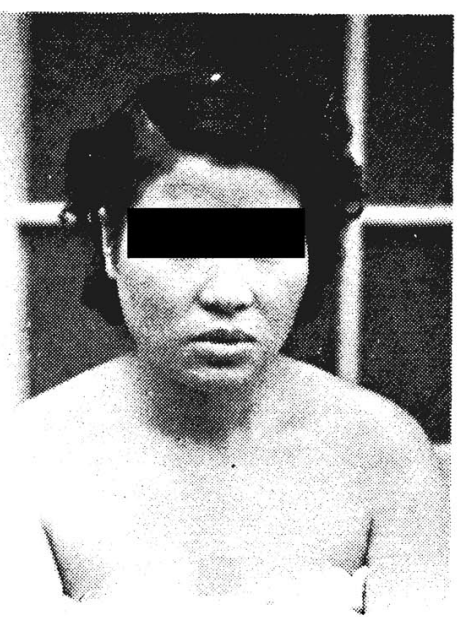

絬 節 然第 3 例

(27. 1. 27)

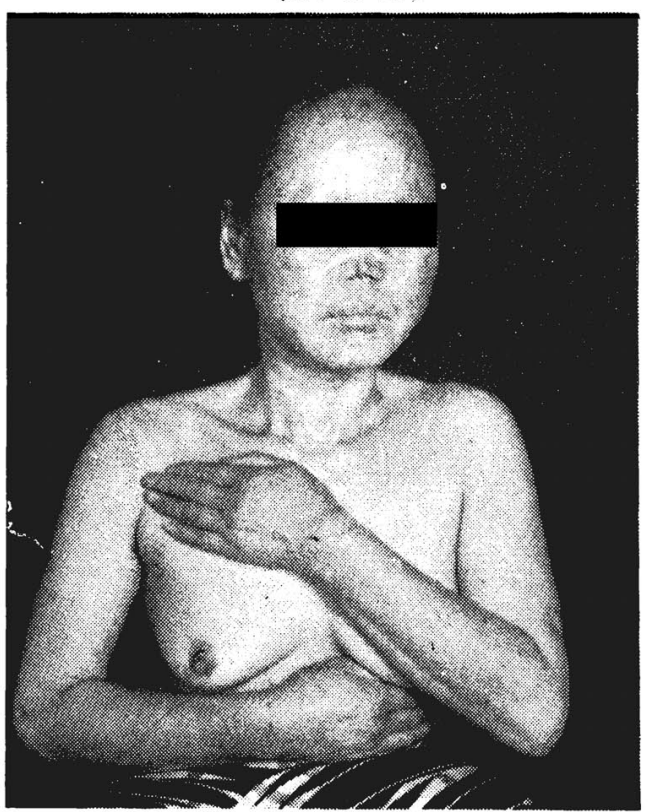


(26. 5. 21)

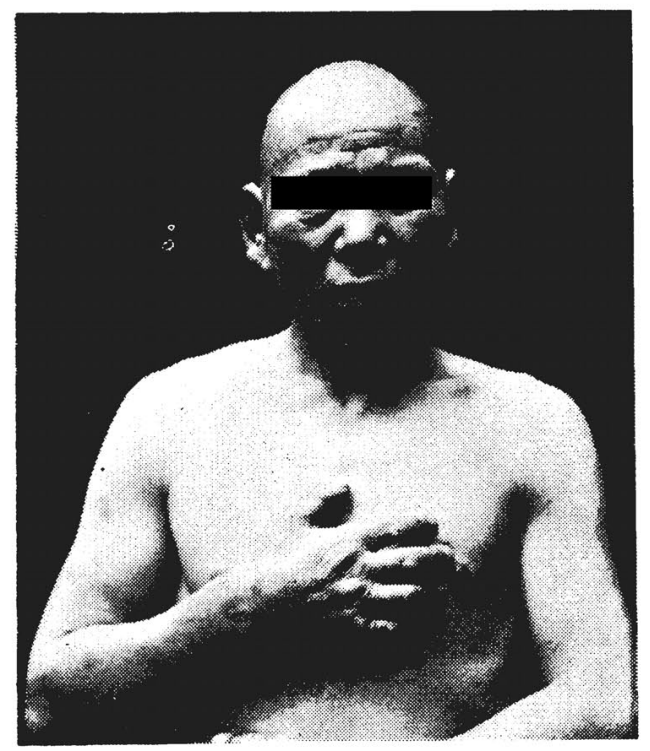

PLATE 5

(26. 5. 21)

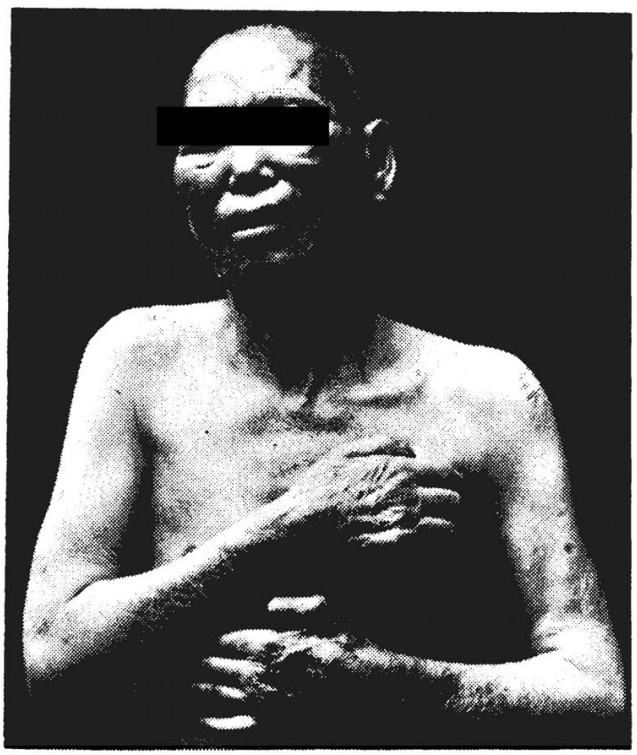

(28. 6. 29)

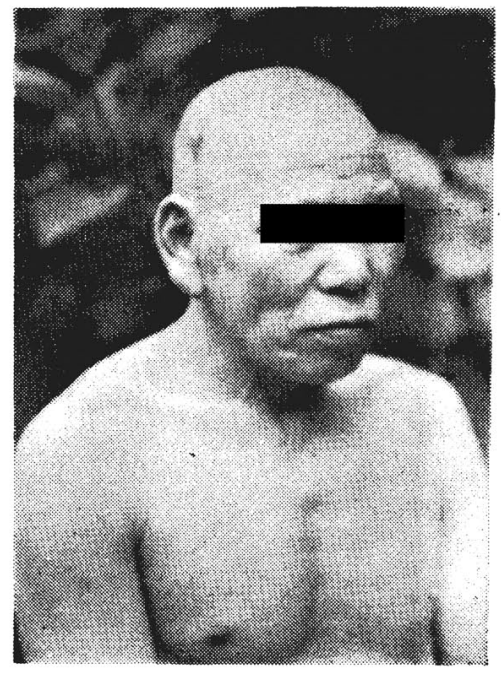

結 節 型第 8 例

(28. 10.27)

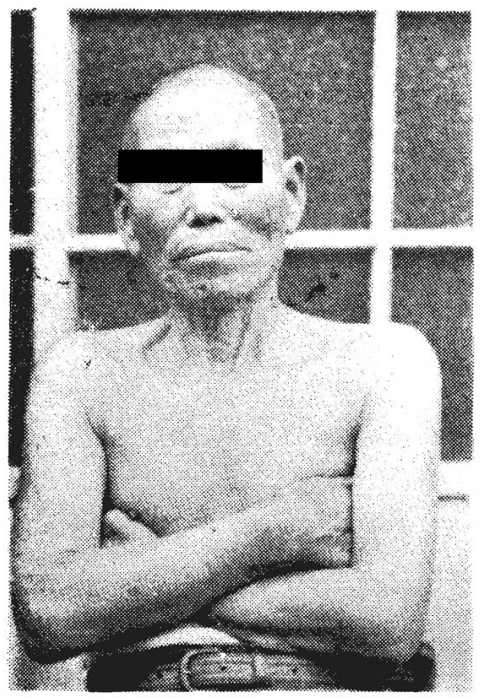




\section{早田論交 附図 (3)}

\section{PLATE 6 結 節 型第 19 例}

(26. 5. 21)

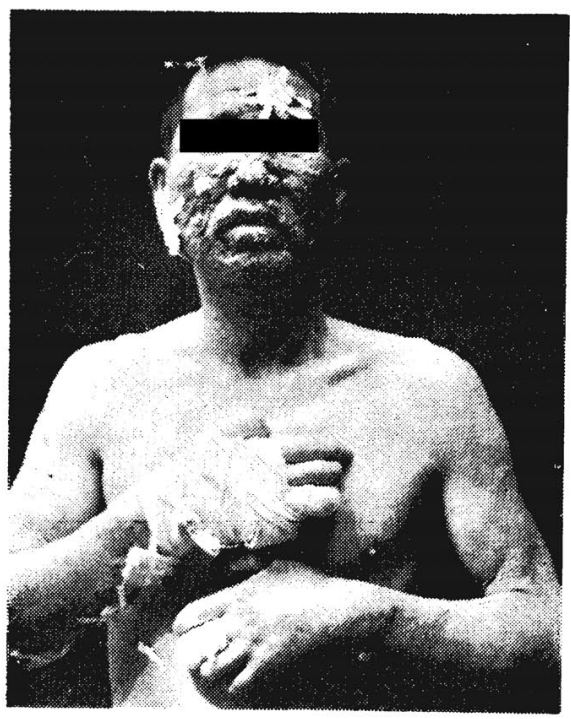

PLATE 7

(26. 8. 17)

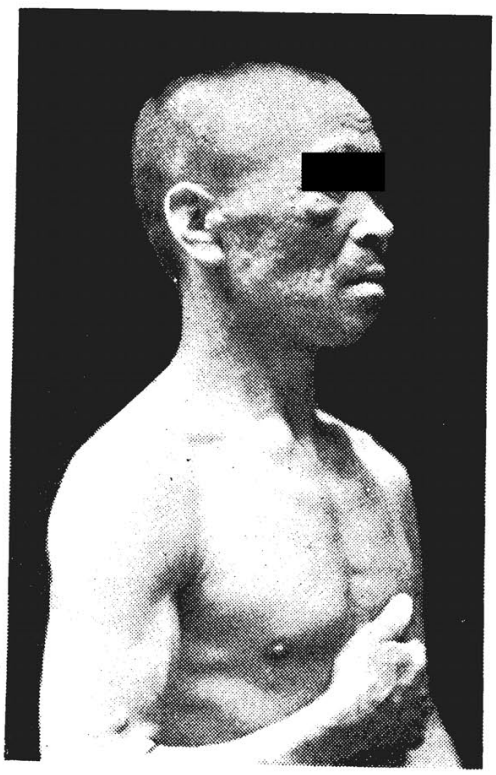

(26. 8. 1)

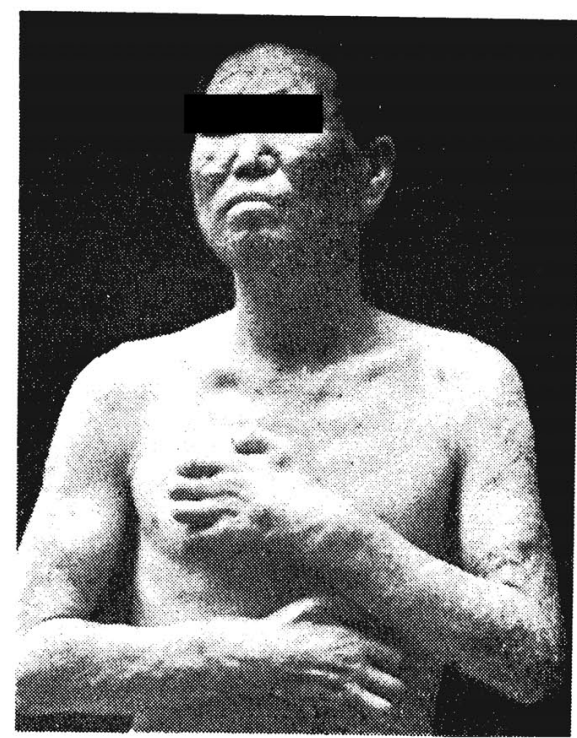

結 節 型第 24 例

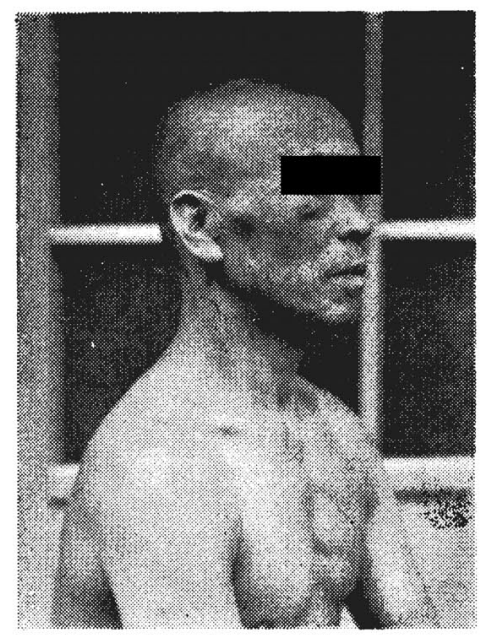


$106-(14)$

早田論文附図 (4)

PLATE 8 結 節 型第 29 例

(27. 3. 8)

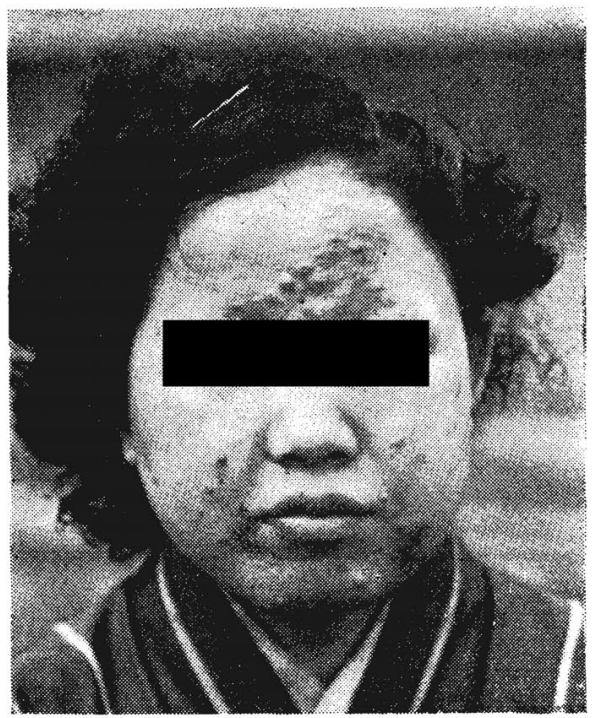

PLATE 9

(27. 8. 27)

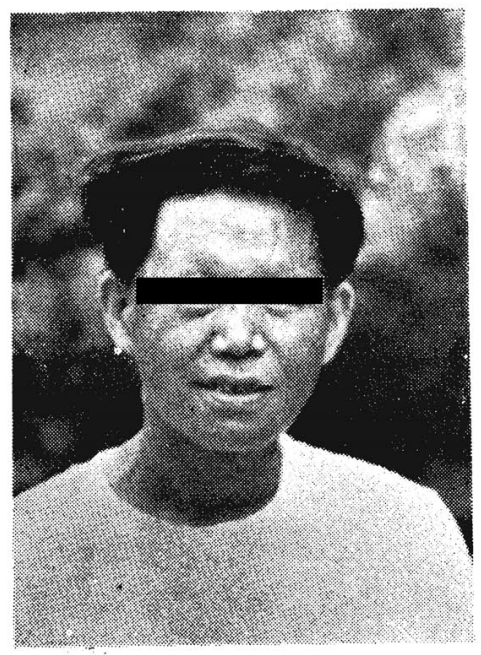

(28. 10. 27)

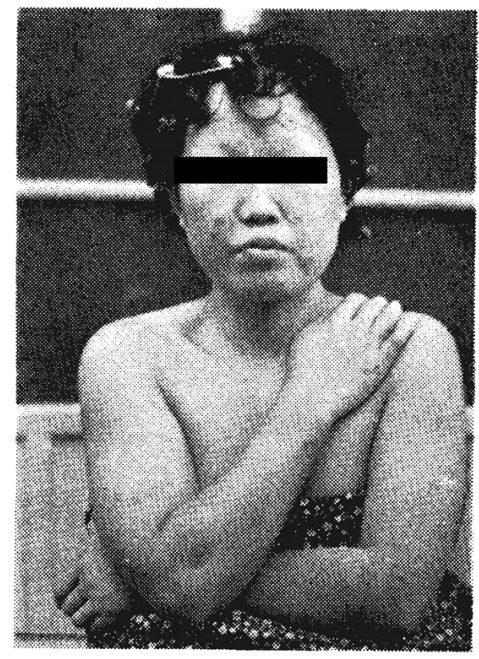

結 節 型第 31 例

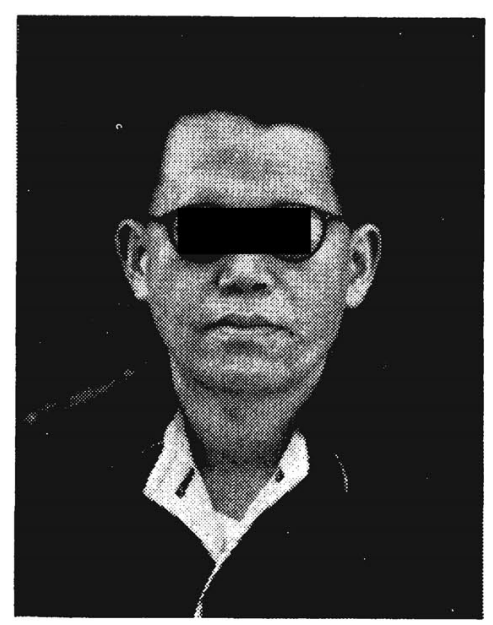




\section{早田諭交附図 (5)}

\section{(27. 8. 27)}

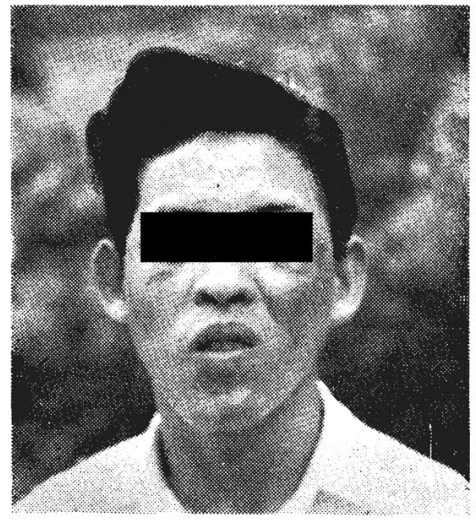

PLATE 11

(27. 8. 27)

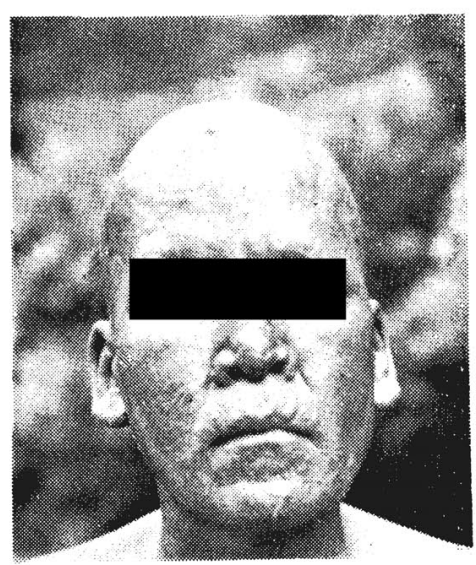

(28. 6. 29)

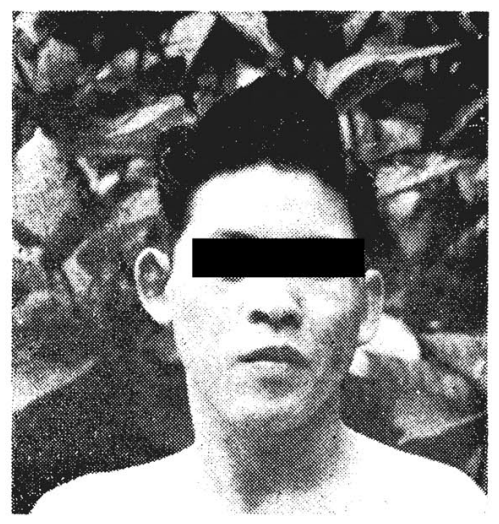

結節型钼 3.1 侧

(28. 6. 29)

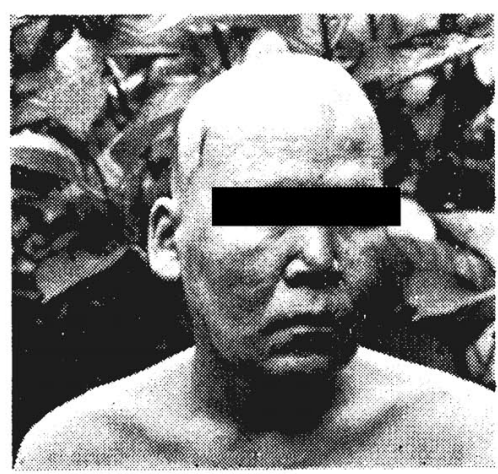




\title{
早田論交附図 (6)
}

\author{
PLATE 12 結節 型第 35 例
}

(28. 2. 18)

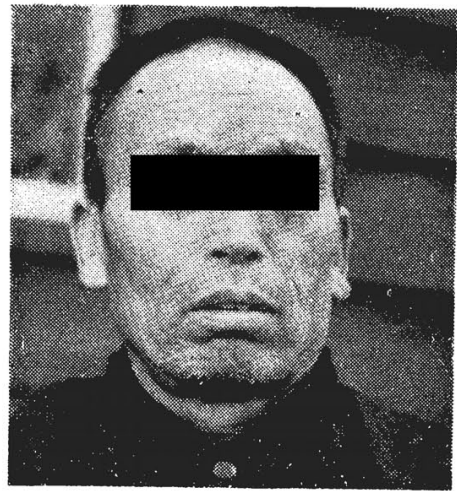

PLATE 13

(28. 8. 5)

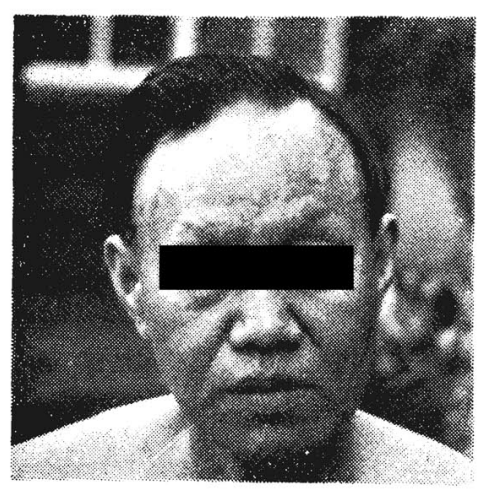

(28. 11. 25)

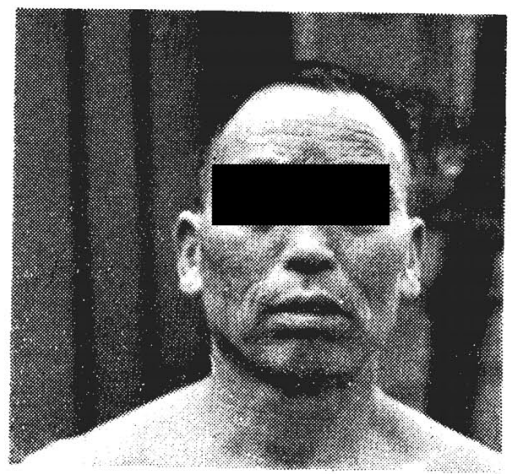

結 節 型第 36 例

(28. 11. 25)

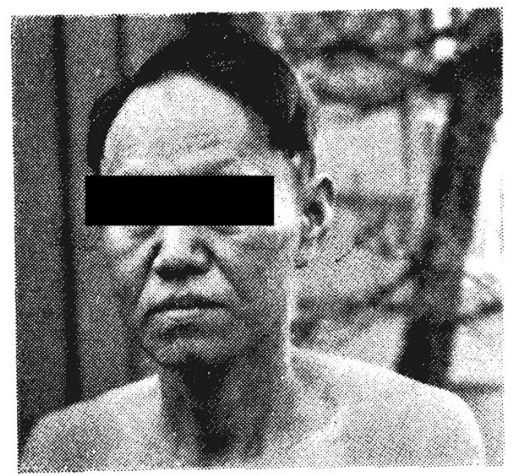

